\title{
Breeding population trends and pre-migration roost site survey of the Red-footed Falcon in Hungary
}

\author{
Peter Palatitz ${ }^{1 *}$, Peter Fehérvári², Szabolcs Solt $^{1} \&$ \\ Éva Horváth ${ }^{1}$
}

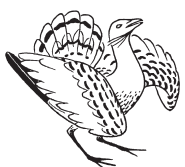

Peter Palatitz, Peter Fehérvári, Szabolcs Solt \& Éva Horváth 2015. Breeding population trends and pre-migration roost-site survey of the Red-footed Falcon in Hungary. - Ornis Hungarica 23(1): 77-93.

Abstract The Red-footed Falcon is a facultatively colonial species that exploits rookeries, nest-box colonies and solitary corvid nests for breeding. Moreover, the remain gregarious in the post breeding period using communal roost sites prior to migration. We developed and implemented a survey protocol to allow to precisely estimate the number of breeding pairs in all three breeding types and to assess large scale spatio-temporal changes in roost site usage. Our results show that the lowest number of breeding pairs (558) was in 2006. However, in 2014 the number of pairs showed a two fold increase, mainly due to a large scale nest-box programme implemented in the past decade. We identified a total of 105 roost sites throughout the country. The number of birds peaked in the second week of September in the past 10 years. We formulate a recommendation to maintain population monitoring efficiency by reducing the frequency of full surveys to 5 years and using designated study areas to control for temporal trends in between.

Keywords: Falco vespertinus, communal roost, post-nuptial migration, post-fledging period, aggregation, monitoring

Összefoglalás A kék vércse egy fakultatívan koloniális madárfaj, mely természetes körülmények között elsősorban vetési varjú telepeken fordul elö, de a fajvédelmi intézkedések keretében létrehozott ládatelepeken is nagyszámban költ. Az őszi vonulás előtti időszakban közös éjszakázóhelyeket használ. 2006-tól a faj sajátosságait figyelembe vevő, költési és vonulás elötti időszakot egyaránt monitorozó protokoll került bevezetésre. A költések monitorozása kiterjedt mind a vetési varjú, mind a ládatelepek, illetve a szoliter párok ellenőrzésére. A premigrációs időszakban új gyülekezőhelyek keresése és az ezeken végzett szinkronszámlálások zajlottak. A korábbi, nem egységesített protokoll szerint végzett felmérések eredményeit is figyelembe véve, a hazai állomány mérete 2006-ban érte el mélypontját, mely azóta növekvő tendenciát mutat. A 2014-es becsült minimális költő állomány elérte az 1250 párt, így az utóbbi évtized fajmegőrzési beavatkozásai során mintegy megkétszereződött.Összesen 105 új öszi gyülekezőhelyet azonosítottunk. A madarak száma a gyülekezökön szeptember második hetében tetőzött. A vizsgált évek eredményei és tapasztalatai alapján egy módosított, kevesebb erőforrást igénylő, de hasonlóan pontos protokollt javaslunk. Eszerint a részletes monitoring tevékenység csak egyes kijelölt területeken zajlana minden évben, országos cenzusra pedig ötévente kerülne sor.

Kulcsszavak: Falco vespertinus, gyülekezőhely, őszi vonulás, állomány felmérés

${ }^{1}$ MME/BirdLife Hungary, Red-footed Falcon Conservation Working Group, 1121 Budapest, Költö utca 21., Hungary, e-mail:palatitz.peter@gmail.com

${ }^{2}$ Department of Zoology, Hungarian Natural History Museum, 1088 Budapest, Baross utca 13., Hungary

*corresponding author 


\section{Introduction}

Long-term monitoring of species specific distribution and abundance patterns provides a fundamental information source for nature conservation efforts (Nichols \& Williams 2006, Gruber et al. 2012). Understanding the factors that play a role in shaping these patterns are crucial to assess the impact of human induced environmental changes (Eglington \& Pearce-Higgins 2012), to help formulate national and international conservation policy (Gruber et al. 2012, Henle et al. 2013), or aid designating specific pin-point conservation measures (Fehérvári et al. 2009, 2012). Albeit avian monitoring in Hungary has a long tradition, systematic or robust design monitoring schemes have only been implemented in the past two decades (Szép et al. 2012). Distribution data on rare, endangered species is sporadic from the communistic era (e.g. Kovács et al. 2008, Horváth 2009) but in the case of Red-footed Falcons (Falco vesperti$n u s)$, a species of high conservation value (strictly protected in Hungary, "near-threatened" in IUCN Red List, ANNEX I of European Commission's Birds Directive 79/409/ EEC), a valuable country-wide survey from the late 1940s (Keve \& Szijj 1957) constitutes an important basis for assessing demographic trends. Here the authors used a questionnaire survey, followed up by a partial census to assess breeding population size in colonies. They estimated 2000-2500 pairs to breed in the country, and showed that the bulk of the population breeds in the eastern part of the country, but the species is widespread in Trans-Danubia (areas west of the Danube) and in the valleys of the foothill region of Northern Hungary (Keve \& Szijj 1957, Fehérvári et al. 2009). The next country-wide assessment from
1990 showed similar population size as in the late '40s with an estimated 2000-2200 pairs (Haraszthy 1998). Regional scale surveys started indicating a considerable decline, for instance Tóth (1995) reports a drastic decrease in Békés County from 1990 to 1995 (550 to 280 pairs). In 1997 the estimated population size was $1300-1400$ pairs, a mere half of what was in 1990 (Tóth \& Marik 1999). Starting from 2003, we initiated an annual country-wide survey that used similar methods to previous estimates. This entailed a combination of estimates of local experts and data from partial census of raptors in general. The results were appalling, showing that the number of pairs is well below 1000 pairs, and continuously decreasing ( 725 pairs in 2003 and 654 pairs in 2005) (Palatitz et al. 2006).

One of the identified population limiting factors that may have largely contributed to the observed decline was the lack of rookeries, as sites for large colonies, in suitable habitats (Palatitz et al. 2009). Rooks have been effectively persecuted throughout the ' 80 s and early ' 90 s, causing a population crash when approx. $90 \%$ of the breeding population disappeared. Moreover, substantial part of the remaining rookeries shifted location to human settlements, further decreasing the number of potential breeding sites (Fehérvári et al. 2009). Several smaller scale initiations have proved that Red-footed Falcons are readily accepting artificial colonies as substitute breeding sites in suitable habitats where rookeries are absent (Csörgey 1908, Molnár 1999, Kotymán 2001). Thus, to halt the negative overall population trend we initiated a large scale nest-box program in 2006 (Palatitz et al. 2010). Initially 3500 nest-boxes were placed out in 2006, to various locations throughout the Hungarian breeding range, 
while today approximately 4000 boxes are readily available in suitable habitats for the birds to breed in.

One of the main motivation behind the high conservation priority of Red-footed Falcons in EU is the negative trend described from eastern Europe, and the case of the documented negative Hungarian population trend. Despite the estimated large global population $(300,000-800,000$ individuals) (Ferguson-Lees et al. 2001), sporadic observations suggests that population trends are negative in various other parts of the breeding range. The European population of 26,000-39,000 pairs suffered a large decline during 1970-1990 (Tucker \& Heath 1994), and has continued to decline during 1990-2000, particularly in the key populations in the former Soviet Union countries, with overall declines exceeding $30 \%$ in ten years (BirdLife International 2004). A national scale survey conducted in Ukraine in 2009 , estimated an approximate decline of $23 \%$ compared to $1990-2000$ (Kostenko, M. unpubl. report). Declines have been reported from eastern Siberia, where the species may have disappeared as a breeder from the Baikal region (Popov 2000). In Serbia, population size decreased while coupled with a concentration of breeding pairs to a smaller country-wide distribution (Purger 1996, 2008, Fehérvári et al. 2012, Barna 2015). However, populations in central Asia appear to be stable, with the species reported as common in suitable habitats in Kazakhstan (especially in forest-steppe zone with Rook colonies), and no evidence of any population declines (Bragin, E. pers. com.).

There is hardly any data available on how these population estimates were made, yet just like in the case of the Hungarian population estimates up to 2005 , they most probably lack the specificity that surveying
Red-footed Falcons necessitates. Therefore, in 2006 we designed a new survey protocol that takes into account the unique breeding biology of these falcons. The most important difference from other raptors in the region is that Red-footed Falcons are facultatively colonial. Colonies are predominantly formed in rookeries (Csörgey 1908, Horváth 1956, Purger \& Tepavčević 1999), while other nest aggregations like magpie nest concentrations are rare (Végvári et al. 2001). The other form of colonial breeding is in artificial nest-box colonies. Monitoring the number of breeding pairs in an artificial colony is straightforward, however in case of rookeries it is challenging. Rook nests are often in the upper third of the canopy, making them difficult to access. Moreover, Red-footed Falcons are relatively late breeders (mean egg laying date: May $27^{\text {th }}$, $\mathrm{n}=1113$ breeding attempts, period: 19952014), thus tree foliage limits visibility of nests in rookeries. This species is also unique in terms of time allocated into mate and nest-site choice. Birds arriving from the wintering grounds may take weeks to finalize settlement decisions (pers. obs.). Meanwhile, their behaviour greatly resembles that of stable pairs; they vigorously defend the chosen nest site from conspecifics, and often mate in the vicinity. However, pairs occupying a given nest cannot be considered as breeders, as they will often change location and/or partners during this period and thus, observers can overestimate the surveyed population. This problem is even more emphasized in the case of solitary pairs. A surveyor, monitoring various other raptors in an area may time field visits to maximize confirmed breeding of most species, however due to the relative late egg laying date of Red-footed Falcons, this period largely coincides with the pre-breeding 
period, when birds are still in the process of making settlement decisions.

A recent, and at that time surprising, discovery revealed that Red-footed Falcons may regularly use communal evening roost sites in large numbers in the post-breeding (premigratory) period (Borbáth \& Zalai 2005). Since then an array of pre-migratory roost sites have been discovered in various countries along the breeding distribution (Kostenko 2009, Fehérvári et al. 2014). This behaviour presents a unique opportunity to monitor spatio-temporal phenology of a little known period in the life-cycle of-migrants (De Frutos et al. 2007, De Frutos \& Olea 2008, De Frutos et al. 2010, Fehérvári et al. 2014).

In this study we describe a novel, species specific survey protocol that allows to monitor Red-footed Falcon breeding and pre-migratory population size and extent. We present results of the implemented survey focusing on recent trends.

\section{Methods}

\section{Breeding population monitoring}

The Red-footed Falcon monitoring protocol designed specifically for the species relies on three corner stones: a) timing of field visits, b) considering detection probability differences in colony types and c) spatial units have to be surveyed $(2.5 \mathrm{~km} \times 2.5 \mathrm{~km}$ UTM square).

We restricted the timing of field visits to monitor falcon breeding in an area to June-July, with at least 2 visits at a given UTM. If a solitary pair is located and breeding cannot be unequivocally confirmed (presence of eggs or nestlings) then at least two further visits have to be made in a minimum of 10 day intervals.
In case of colonial breeding two alternative methods can be applied; either counting adult birds at least twice within June-July (preferably timing it to early mornings or late afternoons) or inspecting (climbing or using mirrors) all nests with the same temporal criteria. The number of breeding pairs in the former case is the maximum number of birds counted in the two events divided by two. Age classes, adult and $2^{\text {nd }}$ calendar year are easily distinguishable based on plumage characteristics (Forsman 1999). Although $2^{\text {nd }}$ calendar year birds are known to breed, but they only constitute a fraction of the breeders. However, they may appear at colonies in relatively large numbers, flocks of up to 100 individuals are not uncommon in the breeding season. Therefore it is paramount to treat the two age groups separately to avoid overestimating the number of breeding pairs at a given colony. We also defined a new category, "occupying pair" to allow retrospect inference on population dynamics. All records that are based on a single observation within the given timeframe, or no other observations confirm breeding, are considered as occupying pairs. Data collection also entailed nest type (i.e. natural nest by building species and nestbox design), geographic location of solitary pairs and colony centers and all identified various threatening factors. Where possible participants also recorded clutch size (number of eggs layed) and the number of hatched and fledged nestlings. We considered a pair's breeding successful if at least one nestling reached an age of 18 days (feathers covering the whole body).

Field work was carried out predominantly by the professional staff of National Park Directorates and members of nature conservation NGOs (60-120 people). Although we designed the protocol to provide 
presence-absence data, over $90 \%$ of UTM squares had breeding records. Presumably, most of the participants had previous local knowledge of the surveyed area, had preconceptions on potential breeding locations and the habitat preference of the birds. Moreover, NATURA 2000 sites were considered as top priority in surveys of not only Red-footed Falcons but for various other species. These preconceptions and the lack of spatial robust design may in theory severely bias results. Detection probability of the species depends on breeding type, however even in case of solitary pairs the chance of false negative data within a UTM square is considered relatively rare. The birds are conspicuous throughout the breeding season, are often vocal and are less shy of humans than many sympatric raptor species. Moreover, the breeding is closely associated to grasslands that are in general of high conservation value in Hungary and are well known to local experts. Thus, it is unlikely that the results are severely underestimating the general spatial extent, or the number of pairs, however we cannot exclude that solitary pairs breeding in arable habitat dominated landscapes distant from other pairs were missed by the surveyors. Nonetheless we treated the data as presence only partial point count census (Fehérvári et al. 2012).

The described monitoring protocol was first implemented in 2006 and was rigorously used within the project duration of an international conservation program (20062009). In the following years, participants had to meet the requirements of various other protocols (Biotica database, RTM, organization requirements) when monitoring bird populations; meanwhile our design became volunteer based. Consequentially, the reporting willingness and protocol compliance suffered and became spatially hetero- geneous. Nevertheless, certain elements became part of good practice, like differentiating between occupying and breeding pairs and the general timing of field inspections. Therefore, we consider the general population trends as reliable but with a certain error margin. Although, this error is arbitrarily identified, it is predominantly based on annual effects and considers the spatial bias in monitoring effort. A major deficiency is that the exact location of new colonies or solitary breeding sites is not reported from the majority of regions. Thus, the spatial extent of the population in 2010-2014 cannot be assessed with similar precision as in the 2006-2009 period. To avoid bias, we only report distribution patterns from this later period. We reduced spatial data resolution to a $10 \times 10 \mathrm{~km}$ UTM grid to allow a more concise presentation of results.

\section{Roost site counts}

We surveyed the number of birds present on roost sites on a weekly basis from the second week of August to the first week of October in 2004-2014. All estimates at individual sites were made on the same day, simultaneously throughout the country, either by counting birds entering the roost during the evening, or by observing the birds leaving the roost the next morning. One of the most challenging tasks was to locate roost sites, as the birds typically appear in low light conditions, thus to locate the exact place the observer has to be within a couple of hundred meters. Moreover, as opposed to other gregarious falcons (Amur Falcons - Falco amurensis and Lesser Kestrels - Falco naumanni) in their wintering roost sites, Red-footed Falcons tend to remain silent prior to roosting (pers. obs.), further making pin-pointing the precise location difficult. 


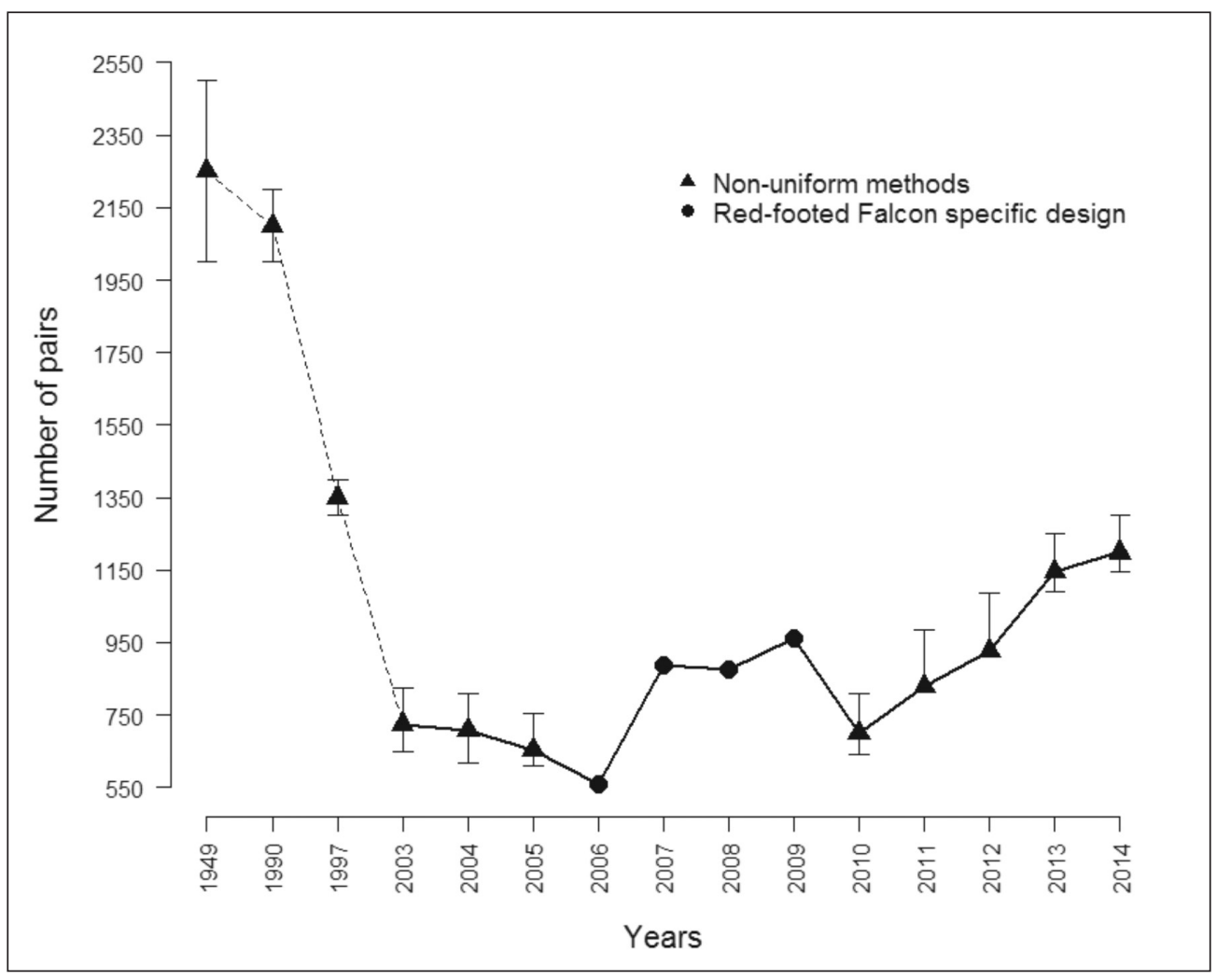

Figure 1. Population trend of Red-footed Falcons from 1949-2014. Whiskers show minimum maximum reported estimates for a given year. In case of 2006-2009 we report the number of occupying pairs assessed via Red-footed Falcon specific survey protocol

1. ábra Kék vércse állománybecslések 1949 és 2014 között. A bajuszsávok a minimum - maximum becsléseket jelzik. 2006-2009 közötti periódusban a kék vércse specifikus monitoring protokoll szerint gyűjtött foglaló párok számát ábrázoltuk

Prior to the weekly counts, observers scanned their area to locate the roost sites in a given season. The most effective method proved to be taking advantage of the fact that the falcons will often travel directly in the direction of the roost site in low altitudes once the daily thermal activity has decreased. Typically, an observer would set out to scan the area of interest late in the afternoon, locate a group of resting individuals, and wait until they leave their location. Once the flight direction is identified, the observers would try and chase the birds and scan for other individuals that may be arriv- ing. Experience and detailed knowledge of the area in question is important as the time period between birds starting to fly at low altitudes and sunset is relatively short. Once a roost is located, the birds tend to use the location within a season, making it possible to reliably estimate the number of birds present.

We categorized roost sites as traditional if birds have used the exact same location (i.e. the same small group of trees or bushes) in at least 3 years of the 10 year study period. All other locations roosts were considered temporary. 


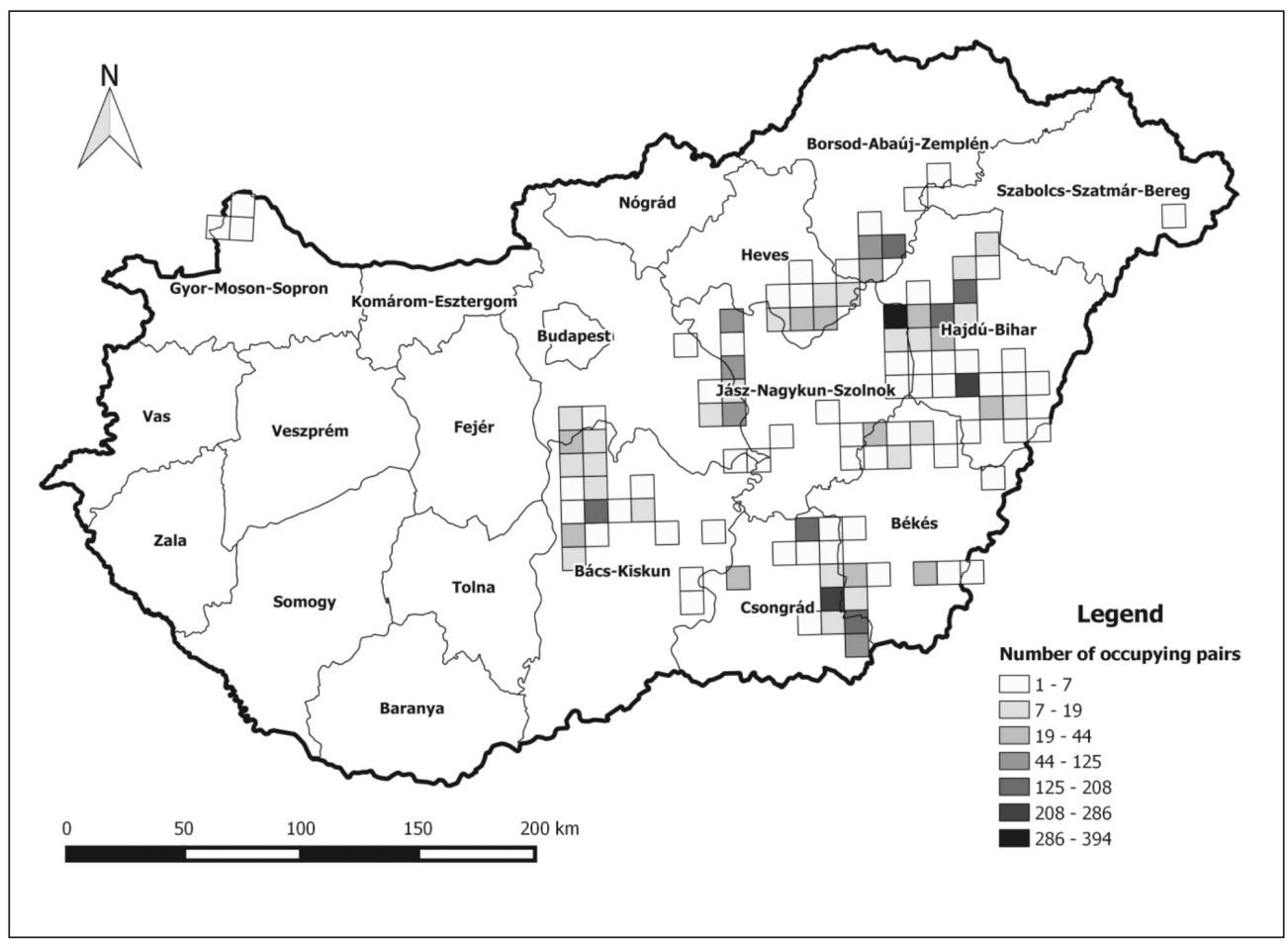

Figure 2. Spatial distribution of Red-footed Falcon occupying pairs in 2006-2009. The results are shown on a $10 \times 10 \mathrm{~km}$ UTM grid

2.ábra A 2006-2009 közötti megfigyelt kék vércse foglaló párok számának térbeli eloszlása. Az adatokat $10 \times 10$ km-es UTM négyzetekben ábrázoltuk

\section{Results}

\section{Breeding population trends}

The Red-footed Falcon population suffered a dramatic over $50 \%$ decline compared to estimates in the 1940s and early '90s (Figure 1). The lowest estimated number of occupying pairs was in 2006 when only 558 occupying pairs were identified in Hungary. The following years produced a fluctuating increase, and by 2014 the estimated breeding population was 1200 pairs.

\section{Breeding population structure and extent in 2006-2009}

Altogether we recorded 3283 occupying pairs in $105,10 \times 10 \mathrm{~km}$ UTM squares within the study period of 2006-2009 (Figure 2). Apart from a few pairs in north-western Hungary, the distribution is concentrated to the south-eastern lowland regions (Figure 2). Despite the relative widespread distribution pattern, the population is concentrated to a handful of large clusters as $65 \%$ of all observed pairs were found in just 10 UTM squares. The proportion of pairs occupying nest-boxes increased significantly (Fisher's exact test: $\mathrm{p}<<0.001$ ) (Figure $3 a$ ) and so did the number of colonial pairs (Fisher's exact test: 


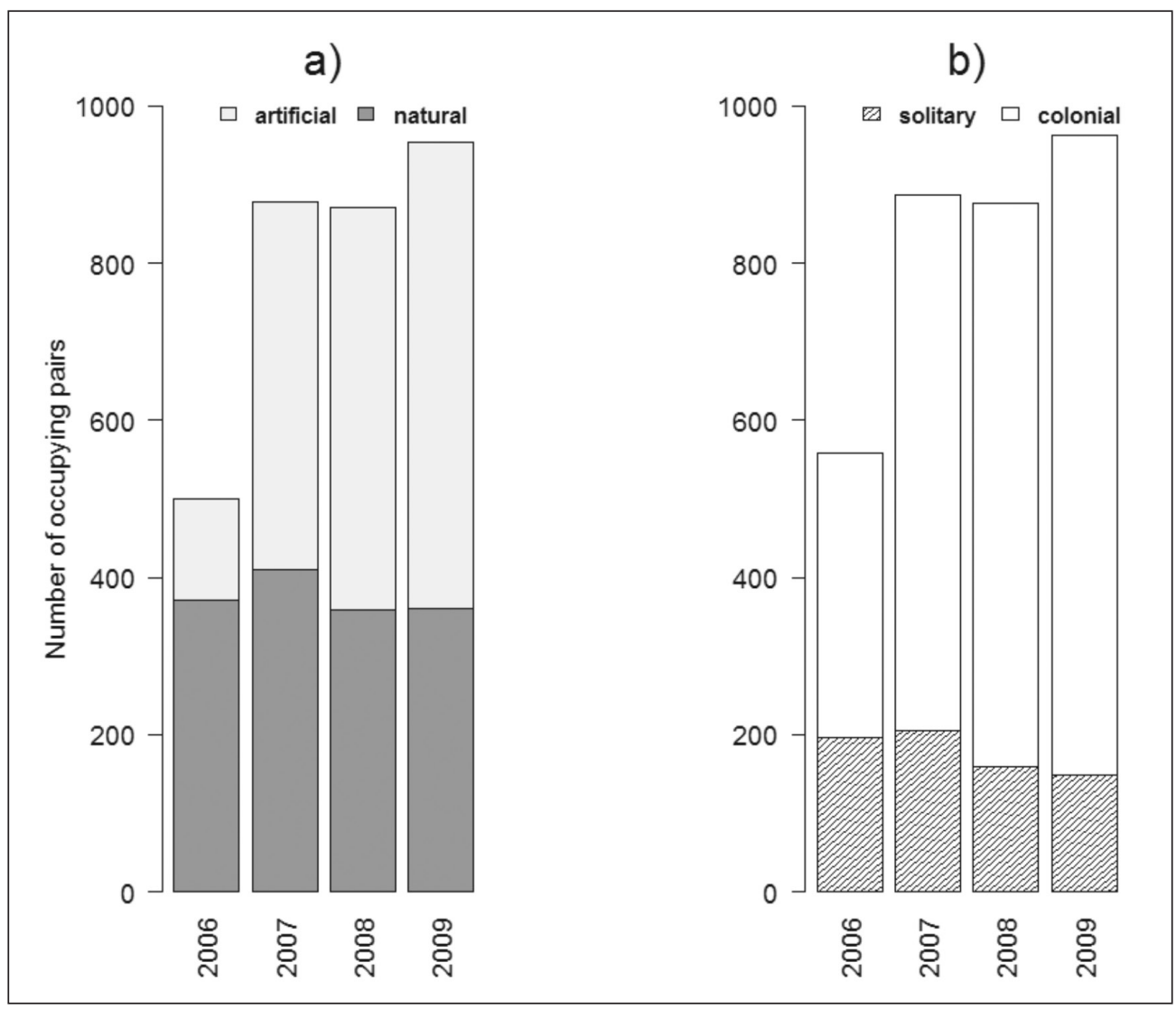

Figure 3. The number of occupying pairs in a) natural vs artificial nests and b) the ratio of solitary vs. colonial pairs in 2006-2009

3. ábra A foglaló kék vércse párok száma a) mesterséges és természetes fészkekben, illetve b) telepes és szoliter párok aránya a 2006-2009 között

$\mathrm{p}<<0.001$ ) (Figure 3b). The ratio of occupying pairs was considerable in the surveyed population and ranged from $17 \%$ to $7 \%$ decreasing gradually during these 4 years.

\section{Roost sites}

We found a total of 105 roost sites, out of which 33 were traditional during the 10 years of the study period. All located roost sites were found within the current breeding range, relatively far from human settlements. The larger traditional roost sites were located close to the centre of the distribution range. The single largest number of birds found was 2000 individuals in the second week of September 2014, near Dévaványa (northern Békés County). Traditional roost sites not necessarily formed in the vicinity of a dense breeding area, in fact the largest ones were in areas with no, or few breeding pairs (Figure 1) (northern Békés, southern Heves and north-western Jász-Nagykun-Szolnok Counties). Small scale (i.e. within a 2-3 $\mathrm{km}$ ) inter-annual roost site displacement was not uncommon. For instance, the roost site in southern Heves County is surrounded by 3 other alternative sites $(0.25-2 \mathrm{kms}$ from the 




Figure 4. The location of traditional Red-footed Falcon roost sites (i.e. used at least in three years of the study period) where the maximum number of birds reached 400 birds at least once in 2004-2014. The circles around coordinates are proportional to the maximum number of birds observed. The figure depicts two distinct traditional roost sites, 1) formed in areas with high breeding density and 2) roosts formed in areas with no or low breeding density. The three largest roosts are of this later type

4. ábra A tradicionális (a kutatási időszakban legalább 3 évben használt) kék vércse gyülekezőhelyek térbeli elhelyezkedése. Azokat a gyülekező helyeket ábrázoltuk, amelyeken legalább egyszer 400 vagy annál több madarat becsültek. A gyülekezők körüli körök arányosak a maximális megfigyelt példányszámmal. Az ábra alapján két tradicionális gyülekezőhely típust lehet elkülöníteni, 1) amelyek sűrű költőállomány közvetlen közelében alakulnak ki, 2) amelyek a sűrű költő területektől távol találhatók. Az utóbbi típusba tartozik a 3 legnagyobb példányszámot magába foglaló gyülekezőhely

depicted location see Figure 4) that the birds have used within the study period. In case of the larger roosts formed in areas with high breeding density, the birds quite often use one of the colonies as roosting sites.

The number of birds gradually increases at roost sites within the pre-migration pe- riod up until the second week of September. In the following weeks, the numbers drastically decline, with only a small fraction of the observed birds remaining in the first week of October (Figure 5, Figure 6). In certain years, the weekly increase of the number birds is not gradual. For instance in 


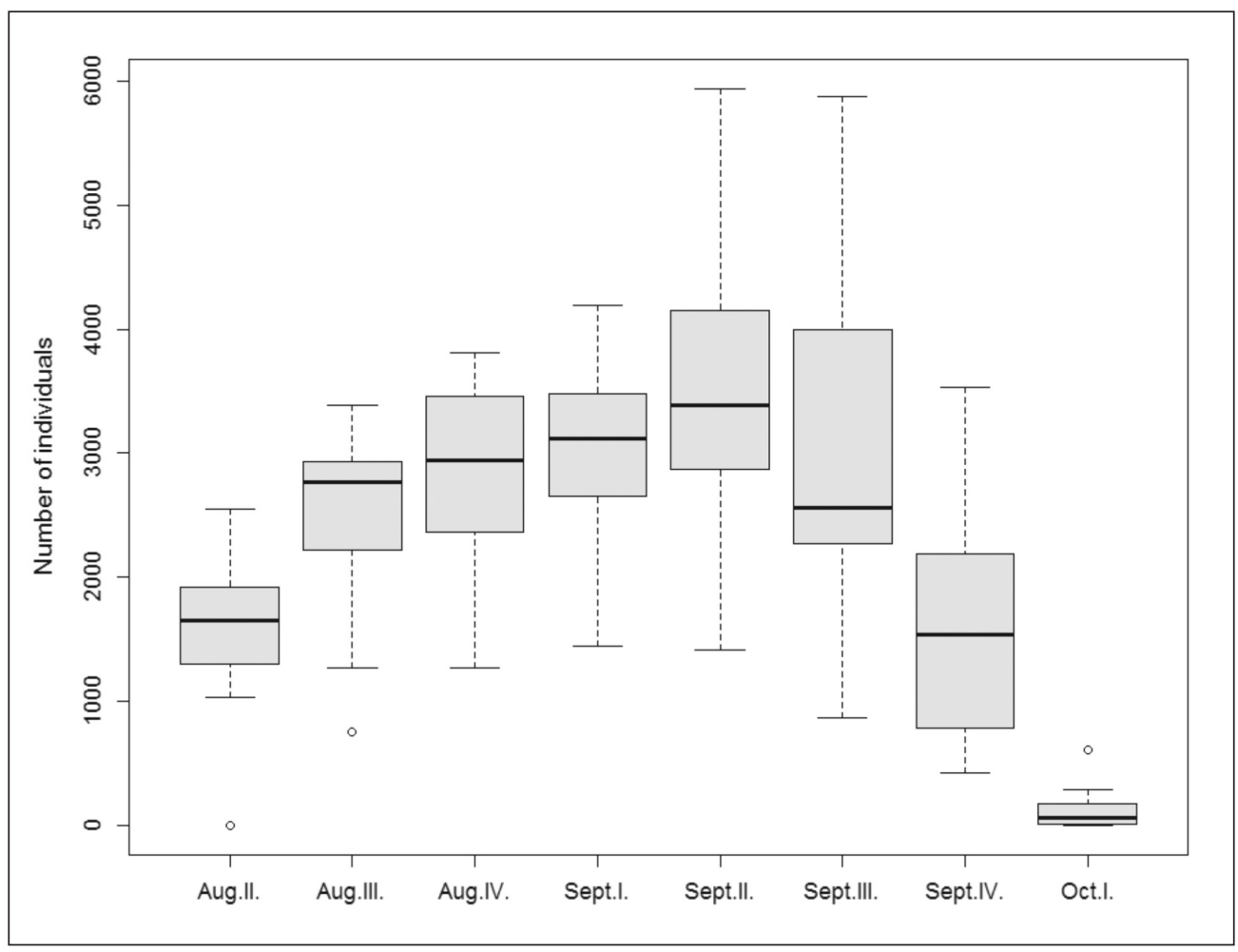

Figure 5. Boxplots of the number of Red-footed Falcons estimated at all roost sites by week of the year in 2004-2014. There is a gradual build up in the number of birds until mid-September, afterwards a steep decline can be observed, with the majority of falcons leaving the roosts within two weeks

5. ábra A gyülekezőhelyeken becsült kék vércsék száma heti bontásban. Graduális növekedés figyelhető meg egészen szeptember közepéig, amikor is a vércsék száma rohamosan fogyni kezd. Szeptember 2. hetét követően a vércsék nagy része 2 hét alatt elhagyja a gyülekezőhelyeket

2009 , the maximum number of birds counted showed a peak compared to previous years, however this was caused by a drastic increase in counted birds during the second week of September (Figure 6).

The overall estimated maximum number of roosting birds fluctuated considerably during the study period (Figure 6). This fluctuation however does not correlate significantly with the annual number of breeding pairs (Spearman's rank correlation: $\mathrm{S}=$ $-122670, \delta=-0.08, \mathrm{p}=0.45$ ) (Figure 7). We found no evidence of change in the mean number of birds roosting within the country during the study period (linear regression: effect of year $=-14.33, \mathrm{SE}=47.05$, $\mathrm{t}$-value $=-0.3$, $\mathrm{p}$-value $=0.76$ ).

\section{Discussion}

\section{Breeding population}

Our results show that the considerably declining breeding population reached a minimum in 2006, when only 558 occupying 


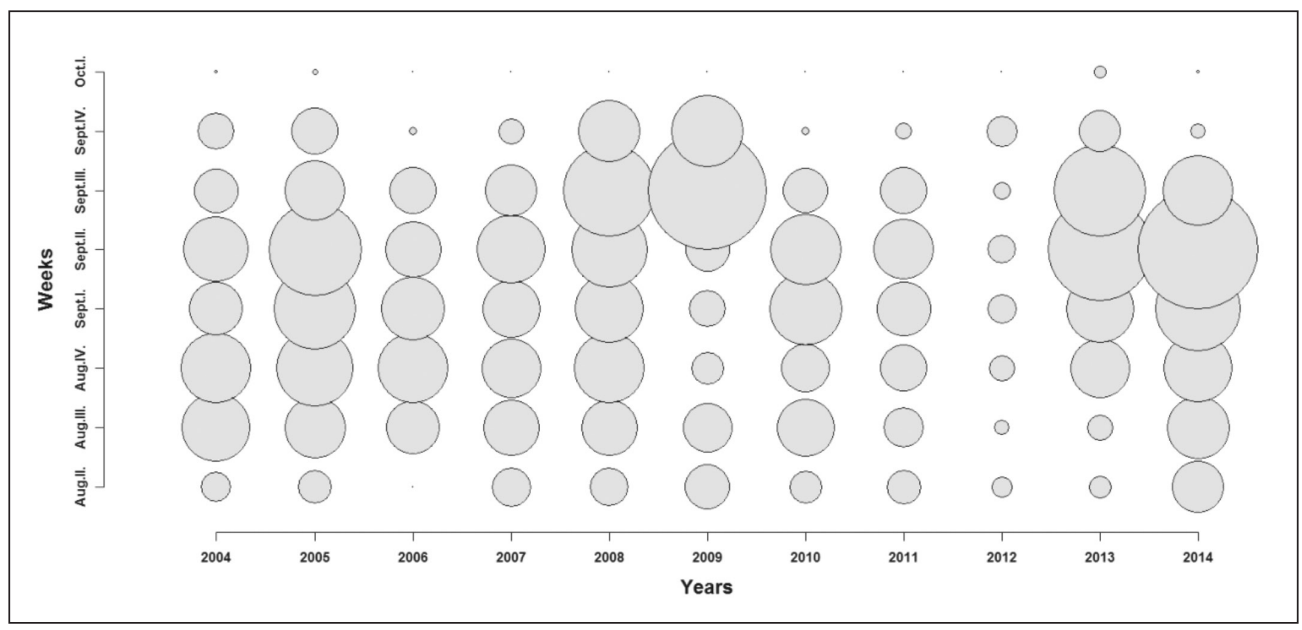

Figure 6. The weekly number of Red-footed Falcons observed during the study period. The area of the circles are proportional to the number of estimated individuals

6. ábra A vizsgált időszakban a gyülekezőhelyeken hetente becsült kék vércse egyedszámok. A körök mérete arányos az összes példányszámmal

pairs were known from Hungary. Considering the fact that single colonies had this order of magnitude pairs in the 1930s and '40s (Schenk 1934, Horváth 1956, Keve \& Szijj 1957), this result was indeed alarming. The large scale nest-box programme initiated in the same year, immediately started showing results and gradually increased the number of breeding pairs, while also shifting emphasis on artificial breeding sites. This increase in the whole population simultaneously affected the ratio of colonial and solitary pairs. While the number of colonial pairs breeding in artificial colonies drastically increased, the number of solitary pairs remained relatively constant in 2006-2009. This is largely due to the fact that nestboxes were placed out predominantly as to mimic rookeries. However, it is yet unclear why a considerable proportion of the Redfooted Falcon pairs choose solitary breeding and that what effect does this altered ratio have an effect on the viability of this population. From a conservation perspective, large aggregation of birds to a small lo- cation increases the importance of localized threatening factors. For instance localized pollution sources, disturbance or predation can have detrimental effect on sizeable proportion of the whole population (e.g. Eeva et al. 2012). Thus, at least in areas where the density of natural nests is low, supplementing nest-boxes for solitary pairs has to be considered to help dilute local effects. The fact that by 2014 the population increased by approx. $100 \%$ and nearly two thirds of the falcons $(25-35 \%$ of the whole EU population) used nest-boxes for breeding shows how limiting the lack of rookeries was. However, nest-boxes, regardless of materials used, wear of and thus need constant maintenance. This conservation dependency of the bulk of the population causes a previously unanticipated potential threat. Nestbox maintenance is resource consuming and necessitates a continuous effort from conservationists and stakeholders (Palatitz et al. 2009). Although we have no exact data on the expected lifetime of the boxes used, but even if it is over 15 years, the majority 


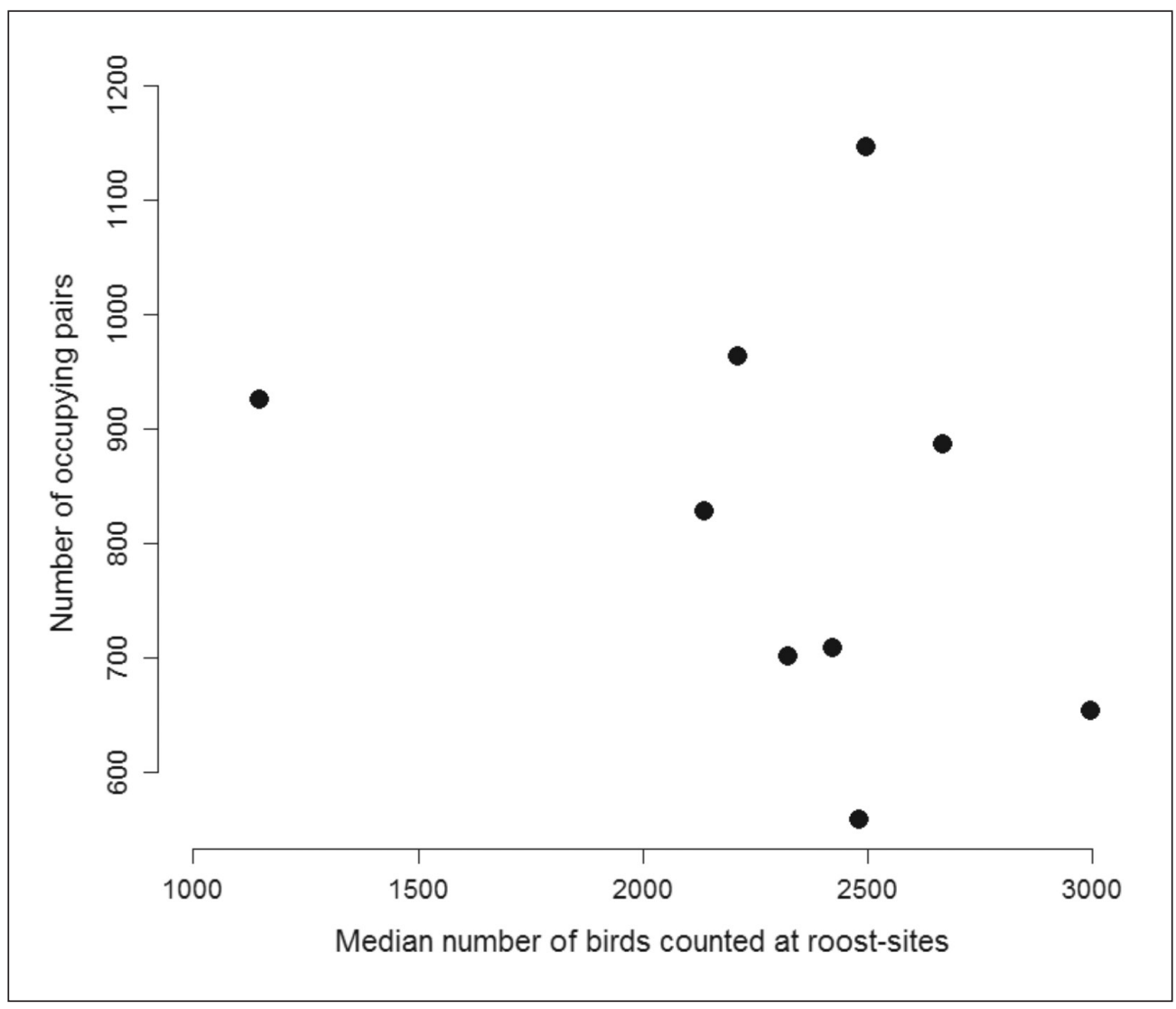

Figure 7. The median number of birds counted at roost sites as a function of the estimated number of breeding pairs in 2004-2014. There is no significant relationship between the two parameters

7. ábra A gyülekezőhelyeken számolt madarak éves mediánja és a becsült foglaló párok száma 2004-2014 között. A két érték között nem volt kimutatható összefüggés

of the now used nests have to be replaced in the following years. If funding is limited or is only regionally distributed, the population size and breeding extent can yet again drastically change in the near future. Artificial colonies, despite their lack of self-sustainability have a clear advantage over rookeries, as their location can be freely chosen given that the surrounding habitats are suitable. Indeed, the majority of artificial colonies today are located in protected areas, reducing potential direct human related threats like illegal felling of nest-box hold- ing trees or disturbance. Rookeries on the other hand, despite the protected status of Rooks, are still subjected to various forms of direct human induced threats. Resolving this conflict is important and initiations have been already implemented (Solt 2008, Horváth et al. 2015), however it is unlikely that law enforcement alone can ensure the viability of the Rook population. Changing the reputation of rooks in the local communities is time consuming and is unlikely to occur in the near future. Presumably, the most successful approach for Red-footed Fal- 
con conservation efforts is to simultaneously manage risks associated with both natural and artificial breeding types and to gradually allocate resources to better understanding of factors limiting the re-expansion of rookeries to natural breeding habitats.

\section{Roost sites}

Our results show that the large scale spatial distribution of roost sites is within the current breeding range. However, the fact that some of the largest traditional roosts are in areas with low breeding densities suggests that habitat requirements in the pre-migration period may be somewhat different. A previous study on diet and foraging habitat use of birds around a single roost site showed that there may be considerable dietary shift compared to that in the breeding period, with small $(<1 \mathrm{~cm})$ insects being the most abundant prey items in the pre-migratory period. Moreover, the birds showed less articulated preference for habitat types as in the breeding period (Széles 2011). These two factors may suggest that the birds shift emphasis to aerial feeding in the pre-migratory period. When analysing the habitat composition of the vicinity of roost sites, we failed to establish models with high predictive power (Széles 2013), while the same was feasible for breeding sites (Fehérvári et al. 2009, 2012). The fact that two traditional roost site types can be differentiated based on the breeding density suggests that alternative strategies may exist. Individuals either utilize an alternative roost or only return to a given roost once during the day, as opposed to the breeding period when numerous foraging bouts are made within a day (Palatitz et al. 2011, Palatitz et al. 2015). This liberates time to allocate into searching resources or other activities, thus the ex- tent of potential habitat use may be orders of magnitude larger than that during breeding (Fehérvári et al. 2014). Correlative evidence suggests that the density of larger prey items like voles may be lower around colonies with the progress of the breeding season (Palatitz 2015). Once the juveniles have fledged and individuals are less constrained to a single location the birds may decide to either remain in the vicinity of the breeding grounds and join roosts there or leave to distant areas with lower breeding densities where traditional roost sites are available. In the former case, the advantage might be local knowledge of the surrounding foraging area with the constraint of potential lower prey densities depleted during breeding in the direct vicinity, while roosts with low breeding densities may have higher prey densities or are close to other food sources that are less available or sufficient during or for breeding.

The within season phenology of the cumulative number of birds at roosts shows that after a steady increase in the first 5 weeks (mid-August to mid-September) the majority of the birds leave the area within two weeks. In case of non-gregarious species that migrate individually autumn migration phenology typically follows a normal distribution like pattern (Knudsen et al. 2007), however in case of Red-footed Falcons this difference may indicate synchronized individual decisions on timing of migration initiation.

We found large inter annual fluctuation in peak number of falcons that is apparently independent from the number of breeding pairs. It is possible that product of mean reproductive output and the number of breeding pairs would show a higher correlation however, data is insufficient to precisely estimate country-wide breeding success for 
the whole study period. Nonetheless, our results may indicate that the number of falcons observed during the pre-migration period is not intimately linked to local breeding. Indeed, satellite tagged birds showed that individual decisions on roost site choice are made on a much larger spatial extent than the area of this study (Fehérvári et al. 2014). These tagged birds used roost sites in southern Ukraine and eastern Romania, and it is plausible to assume that birds breeding in that area may just as well appear within the Carpathian Basin. For instance, in 2009 the number of individuals peaked a week later than in other years, and the observed number of birds was much higher than expected based on the trend observed in previous weeks of the same year. It is possible that this unexpected result was a massive influx of birds from more eastern regions and that either local prey availability or weather drove these birds to the monitored roost sites.

\section{Recommendations}

One of the identified problems is that the developed monitoring protocol is less effective when carried out on a voluntary basis. Therefore, we propose a modification that may allow to assess precise temporal changes in the whole population, while considering bias in survey efforts by participants. As an alternative to conducting annual countrywide complete census point counts, we recommend the designation of at least four $10 \times 10 \mathrm{~km}$ UTM sampling units distributed along the major axes of the breeding range. For instance, a sampling unit in the north-eastern region (Hortobágy), in the western region (Kiskunság), central (Jász-Nagykun-Szolnok and Heves Counties) and in the southern regions (see Kotymán et al. 2015) would probably cover major spatial effect deviations within the breeding range. The complete protocol would be necessary to be implemented annually, and with constant effort within these units. The results obtained would allow for estimating inter-annual effects and major temporal trends, while regionally reducing the allocated resources into monitoring efforts. To assess spatio-temporal changes we propose that a country-wide large scale census should be carried out every 5 years. The protocol for this census can be that one described here with the modification of recording absence data in surveyed UTM squares. Meanwhile future research should concentrate on assessing detection probability of solitary pairs depending on habitat structure.

Nonetheless, it is paramount to continue annually monitoring areas with large aggregation of breeding birds to ensure early detection of localised threatening factors. However, if our recommendations are considered, there is no need to evaluate the number of pairs, their breeding success and various other parameters that are time and energy consuming to acquire in all of these locations.

In case of roost sites, we emphasize the importance of carrying on with annual surveys as they not only provide intriguing results but are inherently helping the protection of roost sites. Weekly presence of surveyors helps ensuring the protection of the birds, and may contribute to early detection of localized threatening factors.

\section{Acknowledgments}

The data presented were mainly collected by rangers of the Hungarian National Park 
Directorates or by volunteers involved to the work of the Red-footed Falcon Conservation Workgroup of MME BirdLife Hungary (falcoproject.eu).

We are grateful for the regional coordinators and gestors of major artificial colonies (Gábor Balogh, Péter Bánfi, Péter Borbáth, Ádám Ezer, Balázs Forgách, Tibor Juhász, László Kotymán, Miklós Lóránt, Csaba Mészáros, Tamás Nagy, Péter Őze, Csaba Pigniczki, Tamás Sápi, Nándor Seres, Gábor Tihanyi, János Tar, Gábor Simay, Antall Széll, Zoltán Vajda, András Vasas, Tibor Vincze) and whose strenuous work provided the background of the conservation of the species (Attila Ágoston, Barabás Lilla, János Bagyura, István Balázs, Péter Barcánfalvi, Krisztián Barna, István Bártol, Csaba Bíró, András Boruzs, Sándor Borza, Ágnes Böde, Krisztián Bránya, Gábor Czifrák, Imre Csáki, Szilárd Daróczi, Miklós Dudás, László Engi, Károly Erdélyi, Sarolta Erdős, Diána Fajka, Imre Fatér, Attila Ferencz, Gábor Firmánszky, Lajos Gál, József Gergely, András Gulyás, Gergő Halmos, Bálint Halpern, László Haraszthy, Dezső Harsányi, Károly Hoffmann, Anett Horváth, Tibor Horváth, József Katona, Zsolt Kepes, Viktor Kis, Anita Kiss, Ádám Kiss, Orsolya Kiss, Róbert Kiss, András Kleszó, Károly Kókai, Sándor Kovács, Anikó Kovács-Hosztyánszki, Atti-

\section{References}

Barna, K. 2015. History and current status of Red-footed Falcon population size and conservation activities in Voivodina. - Ornis Hungarica 23(1): 94-100.

Borbáth, P. \& Zalai, T. 2005. Kék vércsék (Falco vespertinus) őszi gyülekezése a Hevesi-síkon [Autumn roost site of Red-Footed Falcons (Falco vespertinus) in the Heves Plains]. - Aquila 112: 39-44. (in Hungarian with English Summary)

Csörgey, T. 1908. A M.O.K. ezévi müködése a gyakorlati madárvédelem terén [Annual bird conservation report of the M.O.K.]. - Aquila 15: 302305. (in Hungarian and German) la K. Szabó, Bence Lázár, Róbert Lehoczki, Tibor Lengyel, Pál Marik, Bence Máté, László Molnár, Attila Nagy, Károly Nagy, Dóra Neidert, Ákos Németh, Tamás Németh, Csaba Olasz, Zoltán Orbán, Szabolcs Pálfi, Zsolt Pataki, Ildikó Paulikovics, Sándor Imre Piross, Rebeka Saliga, Gergő Simon, Ferenc Pál Szabó, Krisztián Pompola, László Puskás, Éva Sashalmi, János Sasvári, Éva Hegedűs Sasváriné, Zoltán Soltész, Péter Spakovszky, Zsófia Sümegi, Gábor Szalai, László F. Szász, Ottó Szekeres, Balázs Szelényi, Tamás Széles, Zsaklin Széles, Attila Szilágyi, Tamás Szitta, Gergő Szövényi, László Tirják, Béla Tokody, Imre Tóth, László Tóth, János Tögye, Hunor Török, Sándor Török, Ferenc Udvardy, Tibor Utassy, Sándor Ujfalusi, Csaba Vadász, Miklós Váczi, Zsolt Végvári, Tamás Vidra, Levente Viszló, Tamás Zalai, Attila Zelenák).

The monitoring in the study period was founded by the European Commission's LIFE-Nature programme (LIFE05/ NAT/H/000122/ coordinated by KMNPD, managed by Ádám Ezer) Following projects was coordinated by MME BirdLife Hungary (2010-2011 IPA CBC Project 0901/122/120 and 2012-2018 LIFE11/NAT/HU/000926). We acknowledge the continuous support and co-financing of the Hungarian Ministry of Environment and Water.

De Frutos, A. \& Olea, P. 2008. Importance of the premigratory areas for the conservation of Lesser Kestrel: space use and habitat selection during the post-fledging period. - Animal Conservation 11(3): 224-233. DOI: 10.1111/j.1469-1795.2008.00173.x

De Frutos, Á., Olea, P. P., Mateo-Tomás, P. \& Purroy, F. J. 2010. The role of fallow in habitat use by the Lesser Kestrel during the post-fledging period: inferring potential conservation implications from the abolition of obligatory set-aside. - European Journal of Wildlife Research 56(4): 503-511. DOI: $10.1007 /$ s10344-009-0338-4 
De Frutos, A., Olea, P. P. \& Vera, R. 2007. Analyzing and modelling spatial distribution of summering Lesser Kestrel: the role of spatial autocorrelation. - Ecological Modelling 200(1): 33-44. DOI: 10.1016/j.ecolmodel.2006.07.007

Eeva, T., Belskii, E., Gilyazov, A. S. \& Kozlov, M. V. 2012. Pollution impacts on bird population density and species diversity at four non-ferrous smelter sites. - Biological Conservation 150(1): 3341. DOI: 10.1016/j.biocon.2012.03.004

Eglington, S. M. \& Pearce-Higgins, J. W. 2012. Disentangling the relative importance of changes in climate and land-use intensity in driving recent bird population trends. - PLoS ONE 7(3): e30407. DOI: 10.1371/journal.pone.0030407

Fehérvári, P., Harnos, A., Solt, S. \& Palatitz, P. 2009. Modelling habitat selection of the Red-footed Falcon (Falco vespertinus): A possible explanation of recent changes in breeding range within Hungary. - Applied Ecology and Environment 7(1): 59-69.

Fehérvári, P., Lázár, B., Palatitz, P., Solt, S., Nagy, A., Nagy, K. \& Harnos, A. 2014. Pre-migration roost site use and timing of post-nuptial migration of Red-footed Falcons (Falco vespertinus) revealed by satellite tracking. - Ornis Hungarica 22(1): 3647. DOI: 10.2478/orho-2014-0009

Fehérvári, P., Solt, S., Palatitz, P., Barna, K., Ágoston, A., Gergely, J., Nagy, A., Nagy, K. \& Harnos, A. 2012. Allocating active conservation measures using species distribution models: a case study of Red-footed Falcon breeding site management in the Carpathian Basin. - Animal Conservation 15(6): 648-657. DOI: 10.1111/j.14691795.2012.00559.x

Forsman, D. 1999. The raptors of Europe and the Middle East: a handbook of field identification. T \& AD Poyser, London, pp. 589

Gruber, B., Evans, D., Henle, K., Bauch, B., Schmeller, D., Dziock, F., Lengyel, Sz., Margules, C. \& Dormann, C. 2012. "Mind the gap!" - How well does Natura 2000 cover species of European interest? Nature Conservation 3: 45-62. DOI: 10.3897/natureconservation.3.3732

Haraszthy, L. 1998. Magyarország madarai [Birds of Hungary]. - Mezőgazda Kiadó, Budapest, pp. 517 (in Hungarian)

Henle, K., Bauch, B., Auliya, M., Külvik, M., Pe'er, G., Schmeller, D. S. \& Framstad, E. 2013. Priorities for biodiversity monitoring in Europe: A review of supranational policies and a novel scheme for integrative prioritization. - Ecological Indicators 33: 5-18. DOI: 10.1016/j.ecolind.2013.03.028

Horváth, É., Solt, S., Kotymán, L., Palatitz, P., Piross, I. S. \& Fehérvári, P. 2015. Provisoning nest material for Rooks, a potential tool for conservation management. - Ornis Hungarica 23(1): 22-31.

Horváth, L. 1956. The life of the Red-legged Falcon (Falco vespertinus) in the Ohat Forest. - Acta XI. Congressus Internationalis Ornithologici, Basel 1954. pp. 583-584.

Horváth, Z. 2009. White-tailed Eagle (Haliaeetus albicilla) populations in Hungary between 19872007. - Denisia 27: 85-95.

Keve, A. \& Szijj, J. 1957. Distribution, biologie et alimentation du Facon kobez Falco vespertinus L. en Hongrie [Distribution, biology and allimentation of Red-footed Falcons in Hungary]. - Alauda 25(1): 1-23. (in French)

Knudsen, E., Lindén, A., Ergon, T., Jonzén, N., Vik, J., Knape, J., Roer, J. \& Stenseth, N. 2007. Characterizing bird migration phenology using data from standardized monitoring at bird observatories. - Climate Research 35: 59-77. DOI: 10.3354/ cr00714

Kostenko, M. 2009. Inventory of the breeding population of Red-footed Falcons in Ukraine: Spring-Summer 2009 (Project Report). - Kiev: Ukrainian Society for the Protection of Birds, unpublished report, pp. 51

Kotymán, L. 2001. A vörös vércse (Falco tinnunculus) és a kék vércse (Falco vespertinus) telepítésének gyakorlata a Vásárhelyi-pusztán [Establishing artificial colonies of Kestrels (Falco tinnunculus) and Red-footed Falcons (Falco vespertinus) in the Vásárhelyi-puszta]. - Túzok(6): 120-129. (in Hungarian)

Kovács, A., Demeter, I., Fatér, I., Bagyura, J., Nagy, K., Szitta, T., Firmánszky, G. \& Horváth, M. 2008. Current efforts to monitor and conserve the Eastern Imperial Eagle Aquila heliaca in Hungary. - AMBIO: A Journal of the Human Environment 37(6): $457-$ 459. DOI: 10.1579/0044-7447(2008)37[460:CET$\mathrm{MAC}] 2.0 . \mathrm{CO} ; 2$

Molnár, G. 2000. A kék vércse, a vörös vércse és az erdei fülesbagoly mesterséges telepítésének eredményei a Dél-Alföldön [The breeding of the Red-footed Falcon (Falco vespertinus), Kestrel (Falco tinnunculus) and Long-eared Owl (Asio otus) in artificial nest boxes in the Dél-Alföld region]. - Ornis Hungarica 10: 93-98. (in Hungarian with English Summary)

Nichols, J. D. \& Williams, B. K. 2006. Monitoring for conservation. - Trends in Ecology \& Evolution 21(12): 668-673. DOI: $10.1016 / \mathrm{j}$. tree.2006.08.007

Palatitz, P., Fehérvári, P., Solt, S. \& Barov, B. 2009. European Species Action Plan for the Red-footed Falcon Falco vespertinus Linnaeus, 1766. - European Comission, pp. 49 
Palatitz, P., Fehérvári, P., Solt, S., Kotymán, L., Neidert, D. \& Harnos, A. 2011. Exploratory analyses of foraging habitat selection of the Red-footed Falcon (Falco vespertinus). - Acta Zoologica Academiae Scientiarum Hungaricae 57(3): 255-268.

Palatitz, P., Solt, Sz., Horváth, É. \& Kotymán, L. 2015. Hunting efficiency of Red-footed Falcons in different habitats. - Ornis Hungarica 23(1): 32-47.

Palatitz, P., Solt, S., Fehérvári, P. \& Ezer, Á. 2010. Az MME Kékvércse-védelmi Munkacsoport beszámolója - a LIFE projekt (2006-2009) főbb eredményei [Annual report of the Red-footed Falcon Conservation Working Group; main results of the LIFE project (2006-2009)]. - Heliaca 7: 14-23.

Palatitz, P., Solt, S., Fehérvári, P., Neidert, D. \& Bánfi, P. 2006. Kékvércse-védelmi Munkacsoport 2006. évi beszámolója [Annual report of the Red-footed Falcon Conservation Working Group, 2006]. Heliaca 3: 16-24. (in Hungarian)

Purger, J. J. 1996. Numbers and distribution of Red-footed Falcon (Falco vespertinus) nests in Voivodina (northern Serbia). - Journal of Raptor Research 30(3): 165-168.

Purger, J. J. 2008. Numbers and distribution of Red-footed Falcons (Falco vespertinus) breeding in Voivodina (northern Serbia): a comparison between 1990-1991 and 2000-2001. - Belgian Journal of Zoology 138(1): 3-7.

Purger, J. J. \& Tepavčević, A. 1999. Pattern analysis of Red-footed Falcon (Falco vespertinus) nests in the Rook (Corvus frugilegus) colony near Torda (Voivodina, Yugoslavia), using fuzzy correspondences and entropy. - Ecological Modelling 117(1): 91-97. DOI: 10.1016/S03043800(99)00012-5

Schenk, J. 1934. Tömeges kékvércsetojás pusztulás [Massive number of Red-footed Falcon egg destruction]. - Aquila 34: 395. (in Hungarian)

Solt, Sz. 2008. Vetési Varjú Konfliktuskezelési Terv [Corvus Conflict Management Plan]. - MME/ BirdLife Hungary.

Szép, T., Nagy, K., Nagy, Z. \& Halmos, G. 2012. Population trends of common breeding and wintering birds in Hungary, decline of longdistance migrant and farmland birds during 1999-2012. - Ornis Hungarica 20(2): 13-63. DOI: 10.2478/ orhu-2013-0007

Tóth, I. 1995. Békés megyei ragadozómadár-állomány helyzete és változása [The status and changes in raptor populations of Békés County]. - MME Kiadvány pp. 55. (in Hungarian)

Tóth, I. \& Marik, P. 1999. Kék vércse felmérés [Red-footed Falcon Survey]. - Madártávlat 4: 4-5. (in Hungarian)

Végvári, Z., Magnier, M. \& Nogues, J-B. 2001. Kék vércsék (Falco vespertinus) fészekválasztása és állományváltozása a vetési varjak (Corvus frugilegus) állományváltozásának tükrében 1995-1999 között a Hortobágyon [Nest selection of Reed-footed Falcons (Falco vespertinus) and their population changes in relation to population changes of Rooks (Corvus frugilegus) between 1995 and 1999 on the Hortobágy]. - Aquila 107/108: 9-14. (in Hungarian with English Summary



